\title{
Glutamine Oxidation by Developing Rat Small Intestine
}

\author{
ROBERT E. KIMURA \\ University of Utah Medical Center, Department of Pediatrics, Salt Lake City, Utah 84132
}

\begin{abstract}
Glutamine has been reported to be a major oxidative substrate in adult rat small intestine. The significance of glutamine by developing rat jejunal tissue slices and isolated mitochondria was determined. Jejunum slices from suckling rats actively oxidized glutamine at rates significantly greater than adult slices. Increasing the glutamine concentration $(0.5-4 \mathrm{mM})$ in the assay increased glutamine by jejunum of suckling pups by $30 \%$ compared to a $100 \%$ increase in adult jejunum. Glutamine oxidation by isolated jejunal mitochondria was similar in suckling and adult rat. Glutamine oxidation by jejunum of suckling rat was increased in the presence of $5 \mathrm{mM}$ glucose whereas adult glutamine oxidation was not affected by exogenous glucose. Glutamine inhibited glucose oxidation by jejunum of both suckling and adult rats. In adult jejunal homogenates alanine aminotransferase activity was 2-fold greater than in suckling animals. In the presence of $10 \mathrm{mM}$ aminooxyacetate, a known inhibitor of alanine aminotransferase, glutamine oxidation by jejunum of suckling rat was inhibited by $95 \%$, suggesting that alanine aminotransferase is a major metabolic pathway for the oxidation of glutamine. (Pediatr Res 21: 214-217, 1987)
\end{abstract}

\section{Abbreviation}

BSA, bovine serum albumin

In perfused adult rat intestinal models (1-4), in excess of $25 \%$ of the total $\mathrm{CO}_{2}$ production is produced from glutamine. Less than $20 \%$ comes from fatty acids, glucose, and lactate combined, while $50-60 \%$ comes from ketone bodies. Previously, we reported that the oxidation of substrates (glucose, pyruvate, acetate, fatty acids) entering the citric acid cycle at the level of acetyl$\mathrm{CoA}$ is suppressed during the suckling period (6). Neonatal rat pups consume a majority of their calories in the form of fatty acids while they suckle and the liver ketogenesis from fatty acid oxidation results in high serum levels of 3-hydroxybutyrate and acetoacetate. Page et al. (7) determined that serum 3-hydroxybutyrate concentrations in suckling rats are three times greater than in weaned pups and six times greater than in adults. This ketotic condition is similar to that seen in fasting adult rats.

Glutamine oxidation by adult small intestine has been reported not to be affected by starvation. Hanson and Parsons (4) demonstrated that fasted rats showed no change in glutamine oxidation in vascularly perfused jejunum whereas there was a marked suppression of glucose oxidation. Since glutamine oxidation does not seem to be affected by starvation or its related ketosis, we

Received February 10, 1986: accepted October 9. 1986.

Address correspondence Robert E. Kimura. M.D.. Division of Neonatology, Department of Pediatrics. University of Utah Medical Center, 50 North Medical Drive, Salt Lake City. UT 84132.

Supported by NIH Grant GMA-2/2 R01 HD18417-03 ENG. hypothesize that glutamine oxidation may be active during the suckling period. Earlier, we proposed that an increase in intramitochondrial [NADH]/[NAD $\left.{ }^{+}\right]$suppresses glucose and fatty acid oxidation in suckling rat intestine (6). Glutamine enters the citric acid cycle at the level of 2-oxoglutarate, and since glutamine bypasses both citrate synthetase and isocitrate dehydrogenase, the suppression during the suckling period of the citric acid cycle by a high mitochondrial redox state may only partially affect glutamine oxidation. In this study, we investigated the oxidation rate of glutamine in developing rat small intestine and determined substrate preference between glutamine and glucose of suckling rat intestine. The significance of alanine aminotransferase as a major metabolic pathway for glutamine oxidation was determined in developing intestine of the suckling rat.

\section{METHODS}

Tissue preparations. Sprague Dawley rat mothers with litters were obtained from Simonsen Inc. The pups were artificially weaned at 21 days of age to Ralston Purina Rodent Lab Chow 5001 which contains of $4.5 \%$ fat. The animals were killed by decapitation. After removal the intestines were flushed with ice cold $0.9 \% \mathrm{NaCl}$, slit lengthwise, and intestinal slices of $0.5-\mathrm{mm}$ thickness were prepared with a McIlwain tissue chopper. Slices were weighed and used for isolating mitochondria or metabolic experiments.

Isolation of small intestinal mitochondria. The intestinal tissue slices were homogenized using a Teflon homogenizer in a buffer containing $0.25 \mathrm{M}$ sucrose, $20 \mathrm{mM}$ Tris- $\mathrm{Cl} \mathrm{Ph} 7.4,1 \mathrm{mM}$ EDTA, $5 \mathrm{mM} \mathrm{MgCl}, 1 \mathrm{mM}$ ATP, and fat free bovine serum albumin $(4 \mathrm{mg} / \mathrm{ml})$ with a final concentration of $1 \mathrm{~g}$ of tissue $/ 10 \mathrm{ml}$ of buffer. In order to obtain intact mitochondria the intestine was homogenized with only one pass of the Teflon pestle. Cellular debris and nuclei in the homogenate were removed by centrifugation at $750 \times g$ for $15 \mathrm{~min}$. The resulting supernatant was then centrifuged at $27,000 \times g$ for $15 \mathrm{~min}$ and the mitochondrial pellet was resuspended in $0.25 \mathrm{M}$ sucrose $(5 \mathrm{mg}$ protein $/ \mathrm{ml}$ ).

Metabolic assays. Tissue slices, $0.5 \mathrm{~mm}$, were placed into 10 $\mathrm{ml}$ Kontes metabolic flasks containing $1 \mathrm{ml}$ of KRP and substrate (ice cold). The substrates utilized in these experiments were 2 $\mathrm{mM}\left[\mathrm{UL}-{ }^{14} \mathrm{C}\right]$ glutamine $(0.20 \mathrm{Ci} / \mathrm{mol}), 2 \mathrm{mM}\left[3 .{ }^{14} \mathrm{C}\right] 3$-hydroxybutyrate $(0.16 \mathrm{Ci} / \mathrm{mol})$, and $5 \mathrm{mM}\left[\mathrm{UL}-{ }^{14} \mathrm{C}\right]$ glucose $(0.16 \mathrm{Ci} /$ mol). Twenty-five to $50 \mathrm{mg}$ of tissue used unless otherwise designated in the text. The metabolic flasks were sealed in the presence of room air with rubber caps which were fitted with polypropylene center wells (Kontes Glass Co.). The flasks were removed from the ice and the reaction was started by placing the flasks in a shaking water bath at $37^{\circ} \mathrm{C}$. After a 30 -minute incubation, the reactions were terminated by cooling on ice and adding $0.5 \mathrm{ml}$ of $15 \%$ perchloric acid. Hyamine hydroxide, 0.3 $\mathrm{ml}$, was injected through the rubber caps into the polypropylene center well to absorb $\mathrm{CO}_{2}$. The flasks were incubated another 45 min at $37^{\circ} \mathrm{C}$. The hyamine hydroxide was removed and placed in counting vials containing $5 \mathrm{ml}$ of Econofluor for measuring 
radioactivity in a Beckman LS 1800 liquid scintillation counter. To ensure total removal of hyamine hydroxide, the cups were rinsed with Econofluor.

We used a tissue slice technique rather than homogenates so that endogenous pools of substrate and metabolic controls present at the time of animal death were left intact $(5,6)$. A number of criticisms of the tissue slice technique have been raised, including nonuniform diffusion of substrate. This is less of a problem in the intestine where mucosal cells, primarily villous cells, are present as a monolayer and substrate access to these cells is likely to be uniform. Another possible source of error is the presence of endogenous pools of substrate which could dilute the tracer isotopes. To rule out this possibility, we preincubated the small intestine of suckling and postweaned pups prior to adding exogenous substrate and isotope. The calculated rate of either glutamine or 3-hydroxybutyrate oxidation was unchanged in the preincubated groups indicating no significant effect from endogenous pools.

To assess the oxidation of substrates by isolated mitochondria we utilized the same assay technique described above for tissue slices. The incubation solution for glutamine oxidation included $2 \mathrm{mM}\left[1-{ }^{14} \mathrm{C}\right]$ glutamine $(0.1 \mathrm{Ci} / \mathrm{mol}), 130 \mathrm{mM}$ sucrose, $33 \mathrm{mM}$ Tris-Cl (pH 7.4), $15 \mathrm{mM} \mathrm{Na}^{+}$-phosphate, $1.5 \mathrm{mM} \mathrm{MgCl}_{2}, 0.2$ mM EDTA, $2.7 \mathrm{mM}$ ATP and $5 \mathrm{mg}$ BSA. The mitochondria were incubated for $30 \mathrm{~min}$.

Alanine aminotransferase activity (E.C. 2.6.1.12) was determined utilizing the method described by Bergmeyer and Bernt (8). Intestinal homogenates were prepared by vigorously homogenizing $0.5-\mathrm{mm}$ tissue slices in a buffer solution of $0.25 \mathrm{M}$

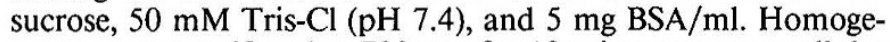
nates were centrifuged at $700 \times g$ for $10 \mathrm{~min}$ to remove cellular

Table 1. Effect of increasing concentrations of glutamine on glutamine oxidation by developing rat small intestine*

\begin{tabular}{ccccc}
\hline & \multicolumn{4}{c}{ Glutamine concentration (mM) } \\
\cline { 2 - 5 } & 0.5 & 1.0 & 2.0 & 4.0 \\
\hline Age (days) & & & & \\
15 & $1.27 \pm 0.14 \dagger$ & $1.43 \pm 0.13 \dagger$ & $1.54 \pm 0.10 \dagger$ & $1.67 \pm 0.20$ \\
& $(7)$ & $(7)$ & $(19)$ & $(7)$ \\
Adult & $0.48 \pm 0.04$ & $0.62 \pm 0.08$ & $0.88 \pm 0.13$ & $0.96 \pm 0.11$ \\
& $(3)$ & $(3)$ & $(10)$ & $(3)$ \\
\hline
\end{tabular}

* Rat small intestine were incubated with increasing concentrations of glutamine. Values represent the rate of glutamine oxidation to $\mathrm{CO}_{2}$ (nmol glutamine oxidized to $\mathrm{CO}_{2} / \mathrm{mg}$ wet weight tissue slice/h). Values presented indicate means \pm SEM (number of animals).

$\uparrow$ Significantly different compared to adult $(p<0.01)$. debris and nuclei. The supernatant was used to determine alanine aminotransferase activity. Protein concentration was determined using the Biuret method (9).

Statistical analysis. Student's $t$ test was utilized as a test of significance unless otherwise noted. In Table 2 a two-way ANOVA with one grouping variable and three related dependent variations were calculated. Within each group a simple one-way ANOVA was calculated. All values are recorded as mean $\pm \mathrm{SE}$.

\section{RESULTS}

Glutamine oxidation to $\mathrm{CO}_{2}$ by developing rat intestine tissue slices. Glutamine oxidation to $\mathrm{CO}_{2}$ by developing rat small intestine was determined in the presence of increasing concentrations of glutamine (Table 1). In the adult small intestine, glutamine oxidation increased $80 \%$ when the concentration of glutamine increased from 0.5 to $4 \mathrm{mM}$ (Table 1 ). In the small intestine of suckling rats the increase was only $31 \%$. The rate of glutamine oxidation to $\mathrm{CO}_{2}$ by small intestine of suckling rat was approximately twice as great as that seen in the adult (Table 1).

The oxidation of glutamine by intestine of suckling rat (Table 2) increases in the presence of $5 \mathrm{mM}$ glucose $(p<0.025)$ and does not change in the presence of $4 \mathrm{mM}$ dl 3-hydroxybutyrate. In adult intestine $5 \mathrm{mM}$ glucose increased glucose oxidation slightly $(21 \%)$ but insignificantly; glutamine oxidation to $\mathrm{CO}_{2}$ in contrast decreased in the presence of $4 \mathrm{mM}$ 3-hydroxybutyrate by $35 \%(p<0.005)$.

The effect of glutamine on glucose oxidation by developing rat small intestine. When glucose oxidation to $\mathrm{CO}_{2}$ was determined in the presence of glutamine (Table 2), the calculated glucose oxidation rate in the intestine of suckling rat was decreased by $60 \%(p<0.001)$. A similar decrease was measured in the intestine of the adult rat. In contrast, the presence of $2 \mathrm{mM}$ glutamine did not affect lactate production at either age.

Glutamine oxidation to $\mathrm{CO}_{2}$ by isolated mitochondria from developing rat intestine. The rates of glutamine oxidation to $\mathrm{CO}_{2}$ by isolated mitochondria from suckling and adult rat small intestine were $46.7 \pm 4.8$ and $57.6 \pm 8.0 \mathrm{nmol}$ glutamine oxidized $/ \mathrm{mg}$ protein $/ \mathrm{h}$, respectively. These data were obtained from 11 experiments.

Alanine aminotransferase activity in developing rat small intestine. Alanine aminotransferase activity was determined using both whole tissue homogenates and subcellular fractions. The majority of alanine aminotransferase activity was in the mitochondrial free supernatant in suckling and postweaned rat small intestine; less than $20 \%$ was in either the cell debris or the mitochondrial fractions (Table 3). In homogenates in which

Table 2. Interaction of glucose, glutamine, and 3-hydroxybutyrate (3-HB) oxidation in intestinal tissue slices*

\begin{tabular}{|c|c|c|c|c|c|c|c|}
\hline \multirow[b]{2}{*}{ Age (day) } & \multicolumn{3}{|c|}{$\begin{array}{l}\text { Glutamine oxidation } \\
\text { to } \mathrm{CO}_{2} \dagger\end{array}$} & \multicolumn{2}{|c|}{$\begin{array}{l}\text { Glucose oxidation } \\
\text { to } \mathrm{CO}_{2}\end{array}$} & \multicolumn{2}{|c|}{$\begin{array}{c}\text { Glucose metabolism } \\
\text { to lactate }\end{array}$} \\
\hline & Cont & $+3-\mathrm{HB}$ & +Glucose & Cont & +Glut & Cont & +Glut \\
\hline $15-17$ & $\begin{array}{c}1.54 \pm 0.1 \\
(19)\end{array}$ & $\begin{array}{c}1.53 \pm 0.1 \\
(10)\end{array}$ & $\begin{array}{c}1.78 \pm 0.12 \\
(14)\end{array}$ & $\begin{array}{c}0.51 \pm 0.08 \\
(4)\end{array}$ & $\begin{array}{c}0.19 \pm 0.01 \ddagger \\
\text { (4) }\end{array}$ & $\begin{array}{c}51.2 \pm 2.4 \\
(4)\end{array}$ & $\begin{array}{c}52.7 \pm 2.4 \\
(4)\end{array}$ \\
\hline $20-25$ & $\begin{array}{c}0.98 \pm 0.07 \\
(10)\end{array}$ & $\begin{array}{c}0.67 \pm 0.03 \S \\
(5)\end{array}$ & $\begin{array}{c}0.91 \pm 0.1 \\
(10)\end{array}$ & & & & \\
\hline $33-45$ & $\begin{array}{c}0.88 \pm 0.13 \\
(10)\end{array}$ & $\begin{array}{c}0.57 \pm 0.07 \\
(10)\end{array}$ & $\begin{array}{l}0.75 \pm 0.09 \\
(10)\end{array}$ & $\begin{array}{c}1.19 \pm 0.07 \\
(4)\end{array}$ & $\begin{array}{c}0.57 \pm 0.02 \ddagger \\
\text { (4) }\end{array}$ & $\begin{array}{c}61.9 \pm 6.7 \\
(4)\end{array}$ & $\begin{array}{c}62.3 \pm 3.3 \\
(4)\end{array}$ \\
\hline
\end{tabular}

* Small intestinal tissue slices of developing rat were incubated with $2 \mathrm{mM}\left[\mathrm{UL}-{ }^{14} \mathrm{C}\right]$ glutamine or $5 \mathrm{mM}\left[\mathrm{UL}-{ }^{14} \mathrm{C}\right]$ glucose. In specified experiments $4 \mathrm{mM}$ Di-3-hydroxybutyrate, $5 \mathrm{mM}$ glucose or $2 \mathrm{mM}$ glutamine were added to the assay mixture. The rate of substrate metabolism to $\mathrm{CO}_{2}$ and lactate were determined. Values indicate the rate of metabolism of substrate (nmol of substrate/mg wet weight tissue/h). Data presented are means \pm SEM (number of animals).

† Statistical analysis of glutamine oxidation using a two-way ANOVA with one grouping variable and three related dependent variables indicated a significant difference between age groups $p<0.001$. This analysis also indicated a significant difference among each of the three dependent variables (control, +3-hydroxybutyrate, and +glucose) $p<0.001$.

$\ddagger$ Values significant compared to control (paired Student's $t$ test $p<0.05$ ). 
cellular debris and nuclei were removed, alanine aminotransferase activity was $63 \%$ greater in the adult than in the suckling rat (Table 3).

The effect of amino-oxyacetate and cycloserine on glutamine and 3-hydroxybutyrate oxidation. Glutamine oxidation to $\mathrm{CO}_{2}$ was determined using tissue slices in the presence and absence of amino-oxyacetate and cycloserine, known inhibitors of alanine aminotransferase. Glutamine oxidation in suckling rat (17-18 days of age) intestine decreased from a control rate of $2.42 \mathrm{nmol} /$ $\mathrm{mg}$ wet weight/h to 1 , and 0.11 in the presence of 5 and $10 \mathrm{mM}$ amino-oxyacetate respectively (Table 4 ). In adult intestine, 5 and $10 \mathrm{mM}$ amino-oxyacetate decreased glutamine oxidation from control values of 1.2 to 0.6 and $0.2 \mathrm{U}$, respectively. These values represent $95 \%$ inhibition of suckling rat jejunal glutamine oxidation and $82 \%$ inhibition of glutamine oxidation in adult intestine. The addition of $10 \mathrm{mM}$ amino-oxyacetate increases the rate of 3-hydroxybutyrate oxidation to $\mathrm{CO}_{2}$ in the suckling by $68 \%$ and adult intestine by $60 \%$. These increases are statistically significant $p<0.05$.

Glutamine oxidation by adult small intestine was inhibited by 2 and $8 \mathrm{mg} / \mathrm{ml}$ cycloserine by 50 and $70 \%$, respectively (Fig. 1). Whereas, glucose oxidation was not affected. Cycloserine (1-8 $\mathrm{mg} / \mathrm{ml}$ ) inhibited 3-hydroxybutyrate oxidation by $25 \%$.

\section{DISCUSSION}

Glutamine oxidation to $\mathrm{CO}_{2}$ by intestinal tissue slices is greater in suckling rat intestine than it is in adult intestine. However, at a high concentration of exogenous glutamine ( $4 \mathrm{mM})$ this difference disappears. Glutamine oxidation to $\mathrm{CO}_{2}$ by isolated intestinal mitochondria of developing rat does not change at the time of weaning. These data suggest that the rate of glutamine uptake

Table 3. Alanine aminotransferase in subcellular cell fractions of developing rat intestine*

\begin{tabular}{lcc}
\hline \multirow{1}{*}{ Subcellular fraction } & Preweaned & Postweaned \\
\cline { 2 - 3 } & (\% of total enzyme activity) \\
\hline Cellular debris and nuclei & 14.4 & 16.3 \\
Mitochondria & 1.6 & 1.8 \\
Mitochondrial free supernatant & 83.9 & 81.9 \\
& enzyme activity in the cellular debris \\
& free supernatant \\
& $(\mu$ mol pyruvate/mg protein $/ \mathrm{min})$ \\
& $0.24 \pm 0.015+(4)$ & $0.394 \pm 0.043(5)$ \\
\hline
\end{tabular}

* Rat small intestine was homogenized in a sucrose-Tris- $\mathrm{Cl}$ buffer. Cellular debris and nuclei was removed from the homogenate by centrifugation at $750 \times g$. Subsequent centrifugation at $27,000 \times g$ for 10 min removed mitochondria. Alanine aminotransferase activity in these various subccllular fractions were measured. Values are means \pm SEM (number of experiments).

$\uparrow$ Value significant from postweaned value $(p<0.025)$. by enterocytes is rate limiting in the small intestine of the developing rat. It has been reported (11) that the uptake of a number of amino acids by developing rat small intestine is high postnatally and decreases after weaning. These authors have noted that the amino acid transport systems in the postnatal rat small intestine appear to be polyfunctional and become more specific after weaning. Although we did not measure glutamine uptake in the present study, an increase in glutamine transport into enterocytes at weaning is consistent with our data.

An alternative explanation for the dependence of glutamine oxidation rate, on glutamine concentration in the intestine of adult rat, might be changes in the brush border of the intestine. The brush border of suckling rats is less developed than in adult animals and diffusion of glutamine in adult animals may be rate limiting.

It has been suggested $(4,12,13)$ that a cellular polarity exists among substrates absorbed from the vascular system and the intraluminal area. Specifically, glutamine absorbed from the vascular space appears to be preferentially oxidized to $\mathrm{CO}_{2}$ when compared to glutamine absorbed from the intraluminal space (4). In our tissue studies, the sources of substrate from the vascular and intraluminal spaces are not delineated. These alterations in the rate of amino acid uptake from the intraluminal space may have profound effects on substrate availability to enterocytes.

Active glutamine oxidation in suckling rat small intestine may be similar to the sparing of glutamine oxidation in adult rats which are starved for $48 \mathrm{~h}$. Both suckling pups and fasted adult rats have elevated blood ketone concentrations. Hanson and Parsons (4) reported that glutamine may play a larger role than

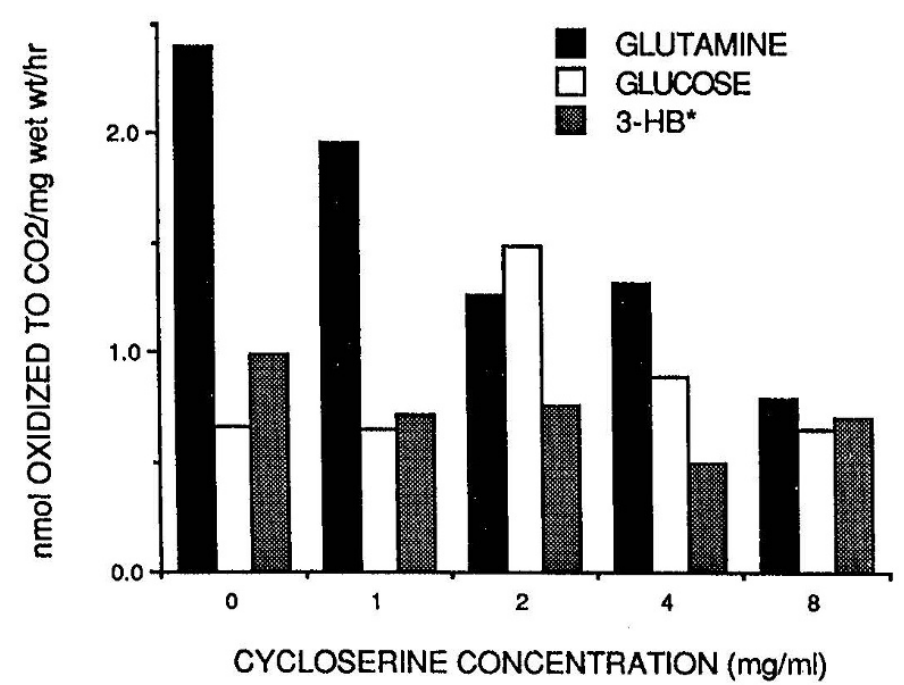

Fig. 1. The effect of cycloserine on small intestinal glutamine, glucose and 3-hydroxybutyrate oxidation; * 3-hydroxybutyrate.

Table 4. Effect of amino-oxyacetate on small intestinal glutamine and 3-hydroxybutyrate oxidation*

\begin{tabular}{|c|c|c|c|c|c|}
\hline \multirow{2}{*}{$\begin{array}{l}\text { Amino-oxyacetate } \\
\text { concentration }\end{array}$} & \multicolumn{3}{|c|}{ Glutamine oxidation to $\mathrm{CO}_{2}$} & \multicolumn{2}{|c|}{$\begin{array}{l}\text { 3-Hydroxybutyrate oxidation } \\
\text { to } \mathrm{CO}_{2}\end{array}$} \\
\hline & 0 & $5 \mathrm{mM}$ & $10 \mathrm{mM}$ & 0 & $10 \mathrm{mM}$ \\
\hline \multicolumn{6}{|l|}{ Age (days) } \\
\hline $16-18$ & $\begin{array}{l}2.42 \pm 0.23 \\
(5)\end{array}$ & $\begin{array}{c}1.1 \pm 0.23 \dagger \\
(4)\end{array}$ & $\begin{array}{c}0.11 \pm 0.01 \dagger \\
(5)\end{array}$ & $\begin{array}{c}0.19 \pm 0.013 \\
(3)\end{array}$ & $\begin{array}{c}0.32 \pm 0.002 \dagger \\
\text { (3) }\end{array}$ \\
\hline Adult & $\begin{array}{c}1.5 \pm 0.09 \\
(3)\end{array}$ & $\begin{array}{c}0.6 \pm 0.04 \dagger \\
(3)\end{array}$ & $0.26 \pm 0.07 \dagger$ & $\begin{array}{c}0.89 \pm 0.15 \\
(5)\end{array}$ & $\begin{array}{c}1.42 \pm 0.17 \dagger \\
(5)\end{array}$ \\
\hline
\end{tabular}

* Small intestinal tissue slices were incubated with increasing concentrations of amino-oxyacetate. Glutamine and 3-hydroxybutyrate oxidation to $\mathrm{CO}_{2}$ were determined. The unit values indicate the rate of substrate oxidation ( $\mathrm{nmol}$ of substrate oxidized to $\mathrm{CO}_{2} / \mathrm{mg}$ wet weight tisssue slice/h). Values presented are means \pm SEM (number of animals).

† Value significantly different compared to control $(p<0.05)$. 
glucose as an intestinal oxidative substrate since glutamine oxidation is not affected by ketosis and glucose oxidation is suppressed during the starved state. Intestinal glucose oxidation is inhibited by ketones (6). The present results suggest that intestinal glutamine oxidation in suckling rats is not affected by ketones (Table 2).

The intestinal oxidation of substrates which enter the citric acid cycle at the level of acetyl-CoA, glucose, and fatty acid, is low in suckling rats as compared to adult rats. Intestinal glutamine oxidation, however, is active in the suckling rat suggesting that the control of glutamine oxidation is different from glucose and fatty acid oxidation. We have suggested that an alteration in intramitochondrial $[\mathrm{NADH}] /\left[\mathrm{NAD}^{+}\right]$may play a major role in controlling intestinal glucose oxidation in the developing rat (6). We measured an increase in intramitochondrial [NADH]/ $\left[\mathrm{NAD}^{+}\right]$by determining tissue levels of 3-hydroxybutyrate and acetoacetate and we demonstrated that the addition of acetoacetate which would decrease intramitochondrial [NADH]/ [NAD ${ }^{+}$] enhances fatty acid oxidation to $\mathrm{CO}_{2}$ in suckling rat small intestine (Kimura RE, unpublished data). Since the increased intramitochondrial $[\mathrm{NADH}] /\left[\mathrm{NAD}^{+}\right]$in suckling rat small intestine does not affect glutamine oxidation, its affect on citric acid cycle activity must occur prior to the metabolic intermediate, 2-oxoglutarate. The sparing of glutamine oxidation in suckling rats suggests that citrate synthetase and/or isocitrate dehydrogenase are rate limiting rather than 2-oxoglutarate dehydrogenase. These two enzyme systems, which are controlled by intramitochondrial $[\mathrm{NADH}] /\left[\mathrm{NAD}^{+}\right]$, have been shown to be the effective rate-limiting steps in other organ systems, such as the heart and muscle (14).

It is difficult to interpret the experiments in which glucose and ketones are added to glutamine oxidation assays. A decrease in the calculated rate of oxidation may be related to an actual decrease in the rate of glutamine oxidation or may be secondary to dilution of the glutamine isotope. Since both glucose and 3hydroxybutyrate oxidation increased at the time of weaning, it is likely that some degree of dilution of the glutamine isotope did occur at the level of in the citric acid cycle. Utilizing $\left[1-{ }^{14} \mathrm{C}\right]$ glutamine, suckling rat intestinal glutamine oxidation is not affected either by exogenous glucose or by 3-hydroxybutyrate in the suckling rat intestine, indicating that no significant dilution of the $\left[1-{ }^{14} \mathrm{C}\right]$ glutamine occurs. Thus, glucose and 3-hydroxybutyrate oxidation in the suckling rat intestine must be insignificant compared to glutamine oxidation.

Glutamate is metabolized to 2-oxoglutarate by either alanine aminotransferase, asparate aminotransferase, or glutamate dehydrogenase. It has been proposed that alanine aminotransferase is a major pathway of glutamate metabolism to 2-oxoglutarate in small intestine (15). Baverel and Lund (16), using isolated enterocytes and $1 \mathrm{mM}$ amino-oxyacetate, a known inhibitor of both alanine and aspartate aminotransferase, reported that glutamine is still metabolized to $\mathrm{CO}_{2}$ at approximately $40 \%$ of the uninhibited rate. Their data suggest that glutamate dehydrogenase is intact in the small intestine, but probably is not the preferred pathway from glutamate to oxoglutarate. With tissue slices, $10 \mathrm{mM}$ amino-oxyacetate decreased suckling rat small intestinal glutamine oxidation to $\mathrm{CO}_{2}$ by $95 \%$ suggesting that glutamate dehydrogenase activity is low in developing rat intestine. In contrast, $10 \mathrm{mM}$ amino-oxyacetate inhibited adult jejunal glutamine oxidation by $82 \%$, a value significantly different from suckling rats $(p<0.025)$. One explanation for this variability in inhibition of glutamine oxidation is a difference in glutamate dehydrogenase activity. Greater inhibition in suckling jejunum suggests lower glutamate dehydrogenase activity as compared to the adult. We can speculate that during suckling, glutamate dehydrogenase is inhibited by high intramitochondrial $[\mathrm{NADH}] /\left[\mathrm{NAD}^{+}\right]$. The increased inhibition of glutamine oxi- dation by $10 \mathrm{mM}$ amino-oxyacetate (Table 4) could occur if there were toxic effects on the citric acid cycle and the electron transport chain of the intestine. Since 3-hydroxybutyrate oxidation increases in the presence of $10 \mathrm{mM}$ amino-oxyacetate, a toxic effect on intermediate metabolism of the small intestine is not likely.

Alanine aminotransferase activity exists primarily in the mitochondrial free supernatant and the cytosolic fraction and was negligible in the cell debris and in the mitochondria. Wen and Gershoff (17) reported adult intestinal alanine aminotransferase activity to be $1.92 \mathrm{nmol}$ glutamate formation $/ \mathrm{mg}$ protein $/ \mathrm{min}$ in contrast to our measured rate of $0.394 \mu \mathrm{mol}$ pyruvate formation $/ \mathrm{mg}$ protein $/ \mathrm{min}$. These authors homogenized mucosal scrapes in distilled water and determined enzyme activity utilizing hydrazones. We utilized a lactate dehydrogenase enzyme assay to measure production of pyruvate from alanine. In addition, we homogenized whole tissue in a sucrose-Tris buffer, $\mathrm{pH}$ 7.4 , containing $5 \mathrm{mg} / \mathrm{ml}$ of BSA. In prior studies with isolated mitochondria, we found that the BSA helps bind digestive enzymes present in intestinal brush borders. It is possible that the decreased rate of alanine aminotransferase, as reported by Wen and Gershoff (17), is secondary to autodigestion by brush border enzymes.

Acknowledgments. The author wishes to thank Kris Snow and Jasminka Ilich for their technical assistance.

\section{REFERENCES}

1. Windmueller HG, Spaeth AE 1974 Uptake and metabolism of plasma glutamine by the small intestine. J Biol Chem 249:5070-5079

2. Windmueller HG. Spaeth AE 1978 Identification of ketone bodies and glutamine as the major respiratory fuels in vivo for postabsorptive rat small intestine. J Biol Chem 253:69-76

3. Windmueller HG, Spaeth AE 1980 Respiratory fuels and nitrogen metabolism in vivo in small intestine of fed rats. Quantitative importance of glutamine, glutamate, and aspartate. J Biol Chem 255:107-112

4. Hanson PJ, Parsons DS 1977 Metabolism and transport of glutamine and glucose in vascularly perfused small intestine rat. Biochem J 166:509-519

5. Neptune EM, Jr 1965 Respiration and oxidation of various substrates by ileum in vitro. Am J Physiol 209:329-332

6. Kimura RE, Thulin G, Warshaw JB 1984 The effect of ketone bodies and fatty acid on intestinal glucose metabolism during development. Pediatr Res 18:575-579

7. Page MA, Krebs HA, Williamson DH 197! Activities of enzymes of ketonebody utilization in brain and other tissues of suckling rats. Biochem J 121:4953

8. Bergmeyer H-U, Bernt E. 1965 Glutamate-pyruvate transaminase. In: Bergmeyer H-U (ed) Methods of Enzymatic Analysis. Academic Press, New York, pp 846-853

9. Gornall AG, Bardawill CJ, David MM 1949 Determination of serum proteins by means of biuret reaction. J Biol Chem 177:751-761

10. Murphy S, Daniels VG 1979 Postnatal amino acid uptake by the rat small intestine. Changes in membrane transport systems for amino acids associated with maturation of jejunal morphology. J Dev Physiol 1:111-126

11. Younoszai MK, Smith C, Finch MH 1985 Comparison in vitro jejunal uptake of $\mathrm{L}$-valine and L-lysine in the rat during maturation. J Pediatr Gastroenterol Nutr 4:992-997

12. Windmueller HG, Spaeth AE 1975 Intestinal metabolism of glutamine and glutamate from the lumen as compared to glutamine from blood. Arch Biochem Biophys 171:662-672

13. Gangl A, Ockner RK 1975 Intestinal metabolism of plasma free fatty acids. Intracellular compartmentation and mechanisms of control. J Clin Invest 55:803-813

14. LaNoue KF, Bryla J, Williamson JR 1972 Feedback interactions in the control of citric acid cycle activity in rat heart mitochondria. J Biol Chem 247:667679

15. Watford M, Lund P. Krebs HA 1979 Isolation and metabolic characteristics of rat and chicken enterocytes. Biochem J 178:589-96

16. Baverel $G$, Lund $P 1979$ A role for bicarbonate in the regulation of mammalian glutamine metabolism. Biochem J 184:599-676

17. Wen CP. Gershoff SN 1972 Effects of dietary vitamin B6 on the utilization of monosodium glutamate by rats. J Nutr 102:835-840

18. Stegink LD, Filer LJ Jr, Baker GL 1985 Effects of starch ingestion on plasma glutamate concentrations in humans ingesting monosodium $\mathrm{L}$-glutamate in soup. J Nutr 115:211-218 